$\triangle C T A \mathbb{N E O P H I L O L O G I C A}$

UDK: 811.163.6'373.231:811.111

DOI: 10.4312/an.51.1-2.49-62

\title{
Anglo-American Cultural Influence in Slovenia: The Case of Personal Names
}

\section{Eva Sicherl}

\section{Abstract}

The article aims to address the growing tendency of Slovene native speakers towards borrowing English personal names when naming their new-borns. Statistical data confirm that foreign (and, with that, English) names have increased in the past decades, and statistical lists illustrate how in the case of personal names, 'exoticisms' (e.g. Liam, Patrick, Nick, listed among the most popular 200 first names in the 2001-2015 period) compete with name forms that have been adapted and nativised long ago (e.g. Patrik), or are currently being introduced for the first time into Slovene. The influx of name borrowings from English is discussed from the point of view of pragmatic borrowing as advocated by Andersen (2014). A historical overview of the borrowing of English personal names into Slovene is given, and the role of English as the model discussed. Such pragmatically borrowed items carry significant sociolinguistic signals about the borrowers' attitudes, and these are analysed, based on questionnaires completed by parents of children aged 2-6. The significance of Anglo-American cultural influence is thus sought to be evaluated.

Keywords: cultural influence, English, Slovene, personal names 


\section{INTRODUCTION}

The sportspages of Slovene newspapers have recently reported on the achievements of a young Slovene snowboarder, Tim Kevin Ravnjak (b. 1996). Sports results aside, Tim Kevin epitomizes a trend noticeable during the past decades of Slovene parents to choose previously unknown English-sounding and/or English-looking names for their offspring. According to the national statistical data provided by the Statistical Office of the Republic of Slovenia, hereafter SURS, Kevin as a male name first appeared in Slovenia around 1970, gained popularity in 1990, and peaked in 1996. Regionally, about 50 percent of all new-borns named Kevin lived in the north-east of Slovenia, followed by the south-west of the country (about 25 percent) (SURS; cf. Lenarčič 2012: 405). But why have so many Slovene parents in the 1990s decided to name their child Kevin? The unwitting culprit for the popularity of this name is most probably the American actor Kevin Costner, whose acting career peaked between 1987 and 1992. Similarly, the name Tim was first hesitantly used around 1970 in Slovenia, then made a breakthrough after 1990, peaked in 2001, and is still going strong.

However, the naming of a newborn gives the baby identity. The present article aims to shed some light on the role Anglo-American culture may play in the selection of personal names in Slovenia. Slovene parents can choose from a number of original Slovene first names whose etymologies are undoubtedly Slovene (e.g. Mojca, Ajda, Svit, Bor), and there is an even greater pool of names to choose from that have been borrowed in the past from various sources and that are no longer felt to be foreign at all although their origins may be Germanic, Romance, Latin(ate), or Slavic (e.g. Albert, Renato, Aleš, Igor). But during the past few decades, the lists of popular names that are given to new-borns in Slovenia have become increasingly foreign-sounding. Between 1981 and 1990, several English-derived names (e.g. Robert/Robi, Alen/Alan, Elvis, Patrik, Diana, Lana, Samanta and Sabrina) made it onto the list of 200 most popular names of the decade. ${ }^{1}$ The next decade (1991-2000) saw a new influx of (potentially) English names: Kevin, Vanes(s)a, Tara,Alex(ander), Kim, Patrick, Melani(e), Neli, Sarah, Nick, with Diana, Samanta, Alan, and Sabrina still persevering among the top 200. The statistical list for 2001-2015 shows new additions, such as Zara, Liam, Ian and Emma featuring among the top 200. Given that naming a newborn child is one of the most intimate events in a family's life - why do parents feel the need to introduce a foreign(-language) element into this act?

1 The etymological origins of these names are, admittedly, not always English, but English-speaking culture may have played a decisive role in their dissemination. For the criteria on inclusion among names from English source, see section 4.1. However, in some cases it is difficult to pinpoint the source; the currently popular forms Max and Alex may be both German- or English-derived, Laura can be both Italian- or English-influenced. 


\section{METHODOLOGY}

SURS has compiled statistical lists of personal names used in Slovenia from 1931 onwards (available at https://www.stat.si/ImenaRojstva/sl), and these have been used to ascertain if there is indeed a rise in the use of foreign names now as compared to the trends of the past. A comparison of statistical data for the 1961-1970 decade and the 2001-2015 period respectively, analysing the most popular 200 boys' and girls' names for each of these periods with a view to their foreignness has shown a rise by approximately $20 \%$ (cf. Sicherl 2017). This article aims to establish to what extent the newly introduced names have been initiated by a British/ American source. The theoretical framework used in the research is that provided by pragmatic borrowing as advocated by Andersen (2014). Finally, we seek to find out whether parents who prefer foreign names over native ones share any common sociological characteristics and what their reasons were for having opted for names from an English source for their children. Based on questionnaires completed by parents of kindergarten children, some sociolinguistic signals about the borrowers' attitudes are sought to be analysed.

\section{PRAGMATIC BORROWING AND PERSONAL NAMES}

English as the world's lingua franca and the popularity of Anglo-American culture practically throughout the world have resulted in English exerting a major influence on other languages, particularly in certain lexical fields (cf. Andersen 2014: 17). Research on anglicisms has mostly dealt with lexis, but has, in recent decades, begun to move beyond the word level and has started to include pragmatic and stylistic elements (see Prince 1988, Onysko 2009, Treffers-Daller 2010). It is now widely acknowledged that borrowings can convey a broad range of stylistic and pragmatic effects (cf. Onysko and Winter-Froemel 2011: 1550). Andersen thus argues for a broad definition of pragmatic borrowing that also includes associated speaker attitudes, taking into account 'sociolinguistic aspects' and considering 'relevant demographic predictors and factors such as register and style' (cf. Andersen 2014: 18, 24).

The reorientation towards the pragmatic aspects of borrowing has resulted in more research on factors that motivate the use of borrowed lexemes, 'such as the attitudes, symbolic values and prestige associated with the SL culture' (Andersen 2014: 21). Pragmatically borrowed items carry important signals about the borrower's attitudes. Although the influence of English on present-day Slovene is a case of remote language contact, English is nevertheless continuously present on Slovene territory through popular culture (cf. also Šabec 2018). By borrowing 
English personal names (along with other borrowings from English), Slovene speakers participate in global trends, but such borrowing is done idiosyncratically and in a locally specific manner (see also Buchstaller 2008: 26, and Fischer 2015).

A study made by Onysko and Winter-Froemel (2011) explores the pragmatic motivations for lexical borrowing in more detail, and has yielded some findings which can, to a degree, also be applied to the borrowing of English personal names. Borrowing of names is related to linguistic innovation, and the main motive for it is to be found in the prestige and fashion of the SL culture. Undoubtedly, the global spread of the English language has had an impact on naming practices world-wide (for an overview in different languages, see Fischer 2015).

If we bear in mind the huge numbers of male and female names at disposal that already exist in the language and are quite unmarked, any introduction of new, marked name forms may seem superfluous. It is difficult to explain the motivation for the choice of a borrowed name over a native one in strictly linguistic terms. By choosing a foreign name, the parents try to introduce some local colour of the SL culture into their own. Fischer (2015: 238) observes that'the deliberate giving of a name that has been taken from the English-speaking world implies a positive attitude towards the use of the English language and the values it is associated with'. Once a borrowed name becomes popular and frequent, its markedness begins to disappear; that is why we find loanword-exoticism doublets in Slovene such as Patrik and Patrick, the former so'naturalised' that it was borrowed anew as Patrick in the 1990s (similar examples include Ela and Ella, Sara and Sa$r a b)$. The reasons for such borrowing may be sociolinguistically diverse, but in the case of English names used in Slovenia the influence of pop culture and media is probably of primary importance. ${ }^{2}$

\section{BORROWING OF PERSONAL NAMES IN SLOVENIA}

The phenomenon of borrowing personal names is, naturally, not limited to Slovenia. It has been observed elsewhere in Europe and beyond (cf. Lenarčič 2012: 886; see also Gerhards and Hackenbroch 2000, and Fischer 2015). ${ }^{3}$ Name borrowing has also had a long tradition in Slovene culture. Many names of foreign

2 The same phenomenon is observable in Britain and the USA: new names that appear in lists of popular baby names frequently include popular film and TV-inspired first names.

3 The British themselves have had to come to terms with an influx of foreign personal names, such as Gemma, Irene, or Claire. Statistical data, however, should be viewed with some caution: the official UK statistics in 2013 place the name Mohammed/Muhammad just behind the most popular boy name Oliver for newborn boys and before Jack (www.ons.gov.uk). However, Mohammed is used in the UK for the naming of the newborn exclusively by Muslims and as such cannot be described as an import into the English language. 
origin have been present in this area for such a long time that they are no longer felt to be foreign at all, e.g. numerous Biblical names and names of saints that have been fully adapted into Slovene and can be found in variant forms in most other European languages in countries with Christian tradition (Janez, Tomaz). Also borrowed centuries ago and completely adapted are some German names which testify to the strong influence of German culture on practically the entire Slovene territory (e.g. Rudolf, Oto, Karel, Ida, Erna). While names of German(ic) origin can be found throughout Slovenia, certain name borrowings of Italian (e.g. Bruno, Franko) and Hungarian (e.g. Lajoš, Tibor) origins remain restricted to the areas bordering on Italy and Hungary respectively (see SURS). Along with German names, some names that originate in Greek or Latin have been present for a long time and have become completely nativised (e.g. Aleksander, Roman, Dijana, Ksenija, Mohor, Irena). Later additions include names from Slavic languages (e.g. Igor, Vanja, Uroš, Stanislav, Nataša), which are also no longer felt to be foreign at all and are by now deeply rooted. Some of these newer additions to the pool of personal names are variants of the older forms; thus, Nataša co-exists along with Natalija.

During the recent decades, however, increasing numbers of new names of foreign origin have entered lists of birth in Slovenia. Although some of these have become quite familiar (e.g. Karin, Iris, Ingrid, Ula, Arne), others remain exotic and decidedly foreign, particularly if their spellings include non-Slovene characters (e.g. Alex, Max as opposed to Aleks(ander), Maks(imiljan)), a hiatus (e.g. Dorian, Diana instead of the more homely Dorijan, Dijana), or double lettering (e.g. Vanessa, Ulla, Ella, Emma). The current trend in naming newborns in Slovenia therefore seems to be: the more foreign(-sounding and -looking), the better. Another apparent trend is the brevity of names, as increasing numbers of three- or four-letter names dominate the lists. Furthermore, there is a trend towards usage of imaginative names that are created by parents themselves and have no etymological background (see also Lenarčič 2012: 891); these express the name-givers' desire for individuality, are fashionable in a particular period and are expected to go out of use after some time (e.g. Nal, Amar, Nia, Din, Lian, Naj, Ajna, Nejla, Nej, to list just a few from the 2001-2015 top 200-name list).

\subsection{English name borrowings in Slovenia, a brief historical overview}

The time of the first language contact between English and Slovene cannot be established with any certainty, but the indirect contact between these two languages was certainly carried out via the intermediary German language and this took place centuries ago (cf. Sicherl 2015). The German influence is also noticeable in 
some old name borrowings that can be traced back to their British origin. ${ }^{4}$ Thus, the first cultural influence of English is observable in some saints' names.

One of such early borrowings from English is the name Ožbalt (variant $O z \check{z} b o l t$ ), which entered from the German form Oswald, and this can be traced back to the English name Oswald and its Old-English (OE) form Osweald ${ }^{5}$. The $7^{\text {th }}$-century Northumbrian king Oswald became venerated as a saint, and the cult of St Oswald was started in Britain in the Middle Ages, spreading to Western and then Central Europe. ${ }^{6}$ In Slovenia, several churches in the north of the country (Carinthia, Styria) were consecrated to this saint as early as the $12^{\text {th }}$ century, so the name must have been familiar to at least part of the Slovene population since ${ }^{7}$. In Slovene, the name has produced several shortened forms such as $O z \check{z} b e / O z ̌ b e j / O z ̌ b i$, and variants Ožbald/Ožbold/Osvald/Ozvald. Most of these are very rare, but the form Ožbolt has resurfaced since 1991 as a name for newborns, remaining limited to the north of the country. Interestingly, the traditional Carinthian form $O z ̌ b e j$ has gained ground since 1981, and has been on the rise in 2001-2015 (ranking as high as $70^{\text {th }}$ of all male newborn names in that period); while still mostly used in the north, it has also spread to most other regions in Slovenia. Ožbej can serve as a classic example of a name that has been so completely adapted and nativised that its origin is felt to be native Slovene, particularly on account of the typical Carinthian ending $-e j$.

Other early name borrowings whose origins can be traced back to English are Edvard (< Eng. Edward < OE: Eadweard), Edita (Eng. Edith < OE: Eadgyth/ Eadgyō), and Edvin (Eng. Edwin < OE: Eadwine). These are not really perceived to be English at all by the present speakers of Slovene. As names of saints venerated by the Roman-Catholic Church they have spread successfully throughout Catholic Europe and some appear in the Slovene almanacs by Vodnik (17951797) (cf. Lenarčič 2012: 201). They have no doubt made their entrance into Slovene via German, and their popularity varied. Thus, Edvard peaked between 1931 and 1960, produced shortened forms $E d o$ and $E d i$, but only the latter form is still recorded in the top-200 name lists. Edvin may have got a new lease of life

4 However, in the case of Germanic name borrowings, it is also possible that some have come in via continental West-Germanic dialects rather than from the British Isles or that they have had parallel development on both sides of the Channel (see Robert vs. Rupert/Ruprecht below).

5 The etymologies of the names are cited after Hanks et al. (2006), Lenarčič (2012), and Keber (2008). The statistical data on the rankings and regional distributions of individual names are provided by SURS.

6 https://en.wikipedia.org/wiki/Oswald of_Northumbria (accessed October 2017)

7 The first church of St. Ožbalt in Jezersko dates back to the $12^{\text {th }}$ century (Dr. Ferdinand Šerbelj, pers. comm. August 2015), and Sv. Ožbalt ob Dravi is mentioned for the first time as a place name in a document of St. Paul's Abbey in Lavanttal in Carinthia in 1372 (cf.http://www.kam.si/romarske cerkve/ozbalt ob dravi.html; accessed August 2016). 
within the growing Muslim population living in Slovenia (see Lenarčič 2012: 202), on account of its similarity to traditional Muslim names beginning in $E d-$ and/or ending in $-i n .{ }^{8}$ Another saint name that originates from the British Isles, but seems to have gained popularity only recently, is Patrik (Eng. Patrick < Lat. Patricius). It had probably been known as the name of the Irish saint and as such appeared in various Slovene almanacs and in calendars, but had not been used as a personal name prior to 1971 when it started to appear in the national statistics. It entered the list of top 200 personal names in $1981-1990$ ( $155^{\text {th }}$ place), and the next decades saw an even steeper rise in its popularity. It was the $50^{\text {th }}$ most popular name in the 1990s, and rose to the $31^{\text {st }}$ place in 2001-2015. Also statistically recorded since 1971 is the foreign form Patrick, which was likewise on the rise

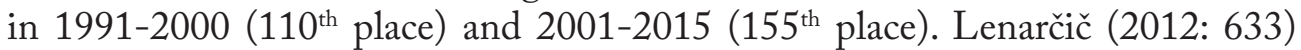
attributes the surge in popularity of Patrik/Patrick to the success of the American actor Patrick Swayze in the 1980s and 1990s.

Apart from Patrik, Ožbej, Edita and Edi, the statistical lists of popular names of the decades following 1960 cite new additions to the pool of personal names used in Slovenia. Judged from the synchronic point of view, some of these have gone completely native on account of their frequency/popularity and their form, which has allowed for unproblematic spelling and pronunciation (e.g. Robert, Alan, Kevin), and, consequently, rapid integration into the language system. Some others remain decidedly foreign-sounding and 'exotic' in the ears of most Slovene native speakers (e.g. Zoe, Rubi, Liam, Ian, Nick, Erin, Emily, Vanessa; the latter are mainly recent imports and still stand out even if their forms are unproblematic in terms of integration). Standing out among these imports is the name Robert as the most successful English-derived name borrowing of all time. It has been present in Slovene prior to 1930 and can be traced back to the German, French and English name Robert or its Latinised variant Robertus (< Old High German: Hrodebert; OE: Hrēodbēorht, Hrodberht, Hrēodbēord, Hrcedbœerd, Hrcedberd; Old French: Robert). The name, however, must have been familiar among Slovenes in an older form Rupert (from Germanic Hrodberht), as proven by place names like Šentrupert. Robert was an immensely popular name for male

8 Lenarčič (2012: 885) argues that names given to their children by Slovene citizens of Bosnian or Albanian origin remain foreign-sounding as they are used to 'express and retain their religious and national identity'. It appears, however, that names such as Tarik and Lejla are now used beyond the Muslim community. Lenarčič (2012: 887) also points out that many parents of Bosnian origin show a preference for names which are neither real Muslim names nor typical Slovene names (e.g. Elvis, Almira), while parents of Serbian or Croatian or mixed origin opt for names which are French, English, or in some other way foreign-sounding. A similar trend has been observed in France with parents of Arab origin, who often choose a Greek name like Yannis/Yanis, the form of which may be reminiscent of Arab names, to avoid the traditional Christian variant Jean (see Lenarčič 2012: 342). 
newborns in Slovenia for two decades, between 1961 and 1980, when it ranked $4^{\text {th }}$ among all male names. It has experienced some decline in popularity since, but has always ranked among the top 200 names. It has been frequent all over Slovenia, and is presently in the $19^{\text {th }}$ place of all male names. It has produced a shortened form Robi, which has been popular since 1971 and can be found throughout Slovenia. The variant Robin is rarely used, but has been constantly present since 1961 when first recorded. The form Robin can also be found used as a female name, but this is much rarer.

Some currently popular names (e.g. Liam, Alan, Ian, Kevin, Tara) can be ascribed English source, though their respective origins may not be English but most often Celtic; however, they have been introduced into Slovene in their anglicized forms. Often the popularity of a name can undoubtedly be attributed to the influence of an English-speaking culture or a prominent personality from that culture enjoying strong media presence (e.g. Elvis, Diana, Kevin, Patrick). Some of these names have undergone interesting development after their adaptation. Thus, Alan, whose origin is either Breton or other Celtic, was first recorded between 1961 and 1970, and then made it to the top 200 male names; it ranked $134^{\text {th }}$ in $1971-1980,137^{\text {th }}$ in $1981-1990,136^{\text {th }}$ in $1991-2000$, and $164^{\text {th }}$ between 2001 and 2015, its popularity prevailing in the south-west of Slovenia. Its popularity was even surpassed by the variant Alen, which ranked $7^{\text {th }}$ between 1971 and $1980,35^{\text {th }}$ between 1981 and $1990,25^{\text {th }}$ between 1991 and 2000, and 39 $9^{\text {th }}$ in 2001-2015. This variant is popular throughout Slovenia, but, again, prevails in the south-west ( $32^{\text {nd }}$ place). However, the form Alen is mainly found among the Croatian, Serbian and Bosnian-Muslim population living in Slovenia (see also Lenarčič and his explanation of the use of the name in ex-Yugoslavia in Lenarčič 2012: 30-31). Elvis (the etymology of the name is not transparent, the origin may be the Irish form Ailbhe) was first recorded as a name in Slovenia between 1961 and 1970, and experienced a sharp rise in pop-

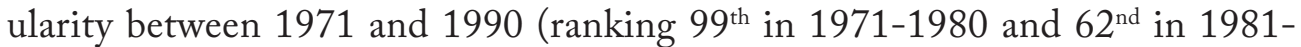
1990). There was some decline between 1991 and 2000 (but still 107 ${ }^{\text {th }}$ rank), after 2000 it left the list of the top 200 boy names. At first, its appearance can be linked to the popularity of Elvis Presley (peaking between 1953 and 1970), but afterwards the name has obviously caught on among the Muslim population of Slovenia irrespective of Presley's fame. Its rankings are highest in the regions with a dense Muslim population, and its use peaked well after Presley's death in 1977. Lenarčič (2012: 213) attributes its popularity among the Muslims to its similarity to some traditional Muslim names beginning in $E(l)$ - and ending in - is, such as Enis (compare similar development of Edvin above). The popularity of Diana/Dijana, although first recorded between 1931 and 1940 and relatively rare in the following decades, rose suddenly between 1981 and 2000, coinciding 
with the media presence of Princess Diana throughout the 1980s and 1990s, and declining after $2001 .{ }^{9}$

Other recent additions from the latest lists provided by SURS are forms like Melani/Melanie, Samanta/Samantha, Sarah, Lana, Ian, Ella, Liam, and Lucas. In most of these cases, statistical data prove regional differences in their distribution. As was the case throughout history, Slovenia's bordering areas seem more prone to the acceptance of foreign names.

Confirming the recent trend of brevity of names, some popular shortened forms from long established names may have been produced under English influence. Thus, Nik may be either shortened from the long nativized forms Nikolaj/Niko, or created from the English form Nick. Similarly, Tim may have been shortened from the traditional Timotej, or modelled after the English name Tim, and Tom either shortened from the traditional Tomaž/Tomi or modelled after the English name Tom.

Finally, the latest trend of unique, creative names can be potentially ascribed to the influence of (particularly) American culture as of that foreign culture that is considered prestigious in the Slovene area. We can assume that the naming practices of Slovene parents are influenced by celebrities from the popular culture and their own names for children. Thus, the trend of unique names seen with Hollywood stars echoes with Slovene celebrities (e.g. names like Shiloh Nouvel and Maddox Chivan in Angelina Jolie's family vs. Šajana and Kanenas for the children of two respective Slovene pop singers) as well as with other young parents in Slovenia. That such naming patterns are actually borrowed has been confirmed by some parents' replies in our questionnaire.

\subsection{English name borrowings in literature and in colloquial use}

Another influence of Anglo-American culture can be detected in abbreviated name forms used in colloquial Slovene. These have not been names given to newborns, but rather fashionable nicknames typically used for grown-ups in the circle of friends and family. Thus, Franc can be referred to as Frenk, Karel as Čarli, and Janez as Džoni.

Žarki se plazijo po tleh, topli. Frenk visi na oknu in stoka, joj, ko bi bil zdaj zunaj. Meni pa je dobro in mirno. (D. Jančar: Noč nasilja; Nova beseda)

Najbolj zadovoljen je bil novi reprezentančni zdravnik dr. Vasja Kruh: nihče ni poškodovan, le Džoni Novak čuti rahle bolečine v desni nogi. (Delo 2000, Nova beseda)

9 The trend of borrowing British royal names may be seen in the popularity of Edvard (see above) in the 1930s and the following decades, and may continue with Zara. Zara is not originally English, it was first used in English in the translation of Voltaire's play Zaïre; alternatively, its popularity in Slovenia may be attributable to the name of the Spanish fashion store Zara. As a girl's name, Zara was first recorded in Slovenia in 2001-2013 and immediately got high rankings $\left(68^{\text {th }}\right)$, becoming popular throughout the area. 
Nič velikega se ne zgodi v Kekcu, čeprav tudi njegova zgodba ni kar tako: Kekec (z vso intenzivnostjo ga predstavlja Žiga Saksida) je postal predsednik Slovenije, in to prav zoprno odločen, Rožle pa je njegov glavni oponent s terorističnimi prebliski ( $z$ zbirko njegovih homemade tempiranih bomb se ukvarja prebrisani Grabnar - Janez Habič Džoni); pravzaprav predstava velike stvari minimalizira do neznatnosti in majhne poveličuje do neznosnosti, oboje s komičnim učinkom. (Delo 2000, Nova beseda)

Pravzaprav je moj drugi najstarejši prijatelj. Prvi je Čarli Novak. Ne po letih. (Delo 2000, Nova beseda)

Somewhat surprisingly, such English nicknames can be found even in the classics of Slovene literature. ${ }^{10}$

"Ne jezi se nad mano, Fanny; glej, zunaj že skoro prihaja jesen in jeseni je moje pregrešno srce najbolj nemirno... Ne jezi se nad mano, Fanny, in oprosti mi, kadar te razžalim." Francka je čutila gorkoto njegovega lica in ni razumela njegovih besed, slišala je samo njegov glas, ki je bil tako mehak in blag, da jo je božal kakor z ljubeznivo roko. (I. Cankar: Na klancu, 1902; https://sl.wikisource.org/ wiki/Na_klancu)

Ko je stala med durmi, se je vzdignil $\mathrm{v}$ postelji, obraz se mu je spačil $\mathrm{v}$ zlobi in $\mathrm{v}$ strahu in klical je s tako hripavo kričečim,sovražnim in prosečim glasom, da se je vzdramil onkraj potoka učitelj Šviligoj, stopil k oknu ter zmajal z glavo. "Beti! Pojdi od mene, ampak tako ne pojdi! (I. Cankar: Ženitba kancelista Jareba, 1907; http://nl.ijs.si/imp/wikivir/d1/WIKI00322-1907.html)

Tvoje življenje pa je kakor drevo, ki bi dajalo žlahten sad lačnim in žejnim. Če naju Bog vidi ..."--" "Cakaj, da ti povem, kako sta Binček pa Suzi ... Minka, na mleko glejte ... kako sta Binček pa Suzi ... o, dobro jutro, Suzi! Kaj pa Binček?“" (I. Cankar: Ponesrečen feljton, 1910; https://sl.wikisource.org/wiki/Ponesrečen_feljton)

\section{ANALYSIS OF BORROWERS' ATTITUDES}

Our final aim is to find out whether parents who prefer foreign names over native ones share any common sociological characteristics and what their reasons were for having opted for names from an English source for their children. For this purpose, a questionnaire was prepared and parents of kindergarten children with (possibly) English-derived names were asked to complete it. In this way, some sociolinguistic signals about the borrowers' attitudes were sought to be analysed.

10 Probably the first to use an English name in his work was the Slovene dramatist Anton Tomaž Linhart with his play Miss Jenny Love (1780). The tragedy, however, was written by Linhart in German. 
First, 50 questionnaires were distributed among parents of kindergarten children aged 2 to 5 to inquire about their child's name(s) and how the choice was made. Thus, we inquired about the child's full name, the names of the parents (and, thus, indirectly, about the parents' origin), the parents' education, their place of residence (village/town/city), and their age. The second part of the questionnaire aimed to establish how the child's name was actually chosen, i.e. was the choice made by both parents, just the mother, just the father, the grandparents or somebody else; the parent was asked to state whether he/she had a preference for traditional/homely names, foreign names, or new/creative names. When asked about the reasons for their choice, the parent could choose among several answers: the name was traditional in their family, the name was quite special and borne by nobody else, the name was identical to that of some friends'/acquaintances'/relatives' child, the name was found in a book of names, the child was named after somebody whom the parent admires, the child was named after a character in a film/book/series, the child was named after a celebrity (e.g. a singer, actor, sportsperson), or the parent was asked to state some other reason for their choice. To verify whether the meaning, longevity and origin of the name had played a role in the name selection process, the parents were asked about these factors as well. They were asked to state whether they were aware of the meaning of the chosen name or not or whether the chosen name intentionally had no meaning and was created by them. As for the longevity, they were asked to state their preference for short names, long names or names consisting of two or more parts (e.g. Ana Marija). When asked about the origin of the chosen name, they had to state whether they had chosen a nativized name, a foreign name, or a name which cannot be assigned an origin. The final part of the questionnaire assessed how premeditated the name choice had been. The parents were asked whether the name had been chosen some time before the birth, in the maternity hospital, or sometime after the birth. Finally, the parents were asked whether the child is now called by its full name or whether the name has been shortened (and into which form) or whether another name is used for the child.

The analysis of 50 questionnaires showed that in only 15 cases the name was undoubtedly English(-influenced), in 10 other cases the influence of English/American was possible (e.g. Kayla), so the results of the analysis presented below should be viewed with caution as the sample is small and conclusions tentative. It turned out that the origin of the parents indeed influenced the name choice: non-Slovene parents from ex-Yugoslavia show a preference for foreign names, usually to express their national/religious identity (e.g. Lejla, Aleksandar), but these are never English-derived. If the chosen name is English-derived, it is given to children coming from entirely Slovene families or mixed families. The factors that were completely irrelevant in the name choice were the parents' education, their age, and place of residence. Whenever an English name was chosen, either both parents were involved 
(83\%; in $16 \%$ of these a sibling had a say too), only the mother (8\%) or only the father (8\%). The parents who had chosen an English name for their child have expressed a preference for foreign names in only $25 \%$ of the cases, $58 \%$ stated they preferred new, creative names, and, understandably, only $17 \%$ liked traditional names. When asked about the reasons for their choice, the influence of the English-speaking cultures comes to the fore: $50 \%$ of the parents have named a film/ book/TV-series character or an actor that had influenced their choice. The rest of the replies show dispersion: the choice was made by a sibling, the name was found in a book of names, or was chosen because it "sounds good with the family name", or was chosen on account of its unproblematic pronunciation (e.g. in the case of a mixed Slovene-Chinese family), etc. When asked about the meaning of the chosen name, only $25 \%$ stated that they were aware of the meaning, to $75 \%$ the meaning of the name was irrelevant. The brevity of the name was another issue: $42 \%$ preferred short names, $17 \%$ preferred long names, none stated a preference for two-part names, and $41 \%$ explicitly said the longevity of the name was irrelevant. The answers about the origin of the chosen name roughly correspond to the replies about their preferences expressed earlier (see above); thus, $42 \%$ preferred foreign names, $8 \%$ preferred traditional homely names (the names they chose were obviously perceived as completely nativized), to the rest the origin was irrelevant. The choice of all English-derived names was premeditated (100\%), the name had always been chosen well before the birth. Finally, all the names seem to have stuck: in only $8 \%$ of the cases the name has been shortened (e.g. Oliver into Oli).

\section{CONCLUSION}

Although parents in Slovenia today are free to choose the name they like, their creative imagination is still largely influenced by existing cultural practices and beliefs (see also Gerhards 2010: 147-153). The deliberate choice of a name taken from an English-speaking culture is underlain by a positive attitude towards the use of the English language and the values it is associated with. The tendencies towards individualization and transnationalization (as suggested by Gerhards 2010) are confirmed, if only indirectly, by the findings yielded by the analysis of borrowers' attitudes (section 5).

When dealing with English-derived names adopted by parents in Slovenia, two groups of names emerge: nativized names with origin that can be traced back to an English-speaking culture, and English-derived and -influenced 'exoticisms' of the latest period (e.g. Zoe, Ruby, Erin). The division between the two groups is not always as clear-cut as one would wish for, and a subgroup can be formed consisting of names that are deviations from long established nativized names, but whose present forms have probably been influenced by a foreign source (e.g. Mark 
instead of traditional Marko). Judging from the parents' answers in the questionnaire, such names are felt to have been nativized already (e.g. Mark, Tim).

Another issue that has been opened up for possible future research concerns the durability of the new names in the language: will Tim Kevin Ravnjak prove to be a model for future name-givers?

With fashion and the aesthetics of names gaining in importance, it can be expected that the pool of names is about to grow in diversity in terms of origin and phonetic/orthographic form. However, it remains to be seen if this trend is to contribute to transcultural hybridity and the formation of multi-ethnic identities.

\section{BIBLIOGRAPHY}

Andersen, Gisle. 2014. "Pragmatic borrowing." Journal of Pragmatics 67, 17-33. Buchstaller, Isabelle. 2008. "The localization of global linguistic variants." English World-Wide 29/1, 15-44.

Fischer, Roswitha. 2015. "English personal names in international contexts." SKASE Journal of Theoretical Linguistics 12/3, 238-256.

Gerhards, Jürgen. 2010. Die Moderne und ihre Vornamen: Eine Einladung in die Kultursoziologie. $2^{\text {nd }}$ edt. Berlin, Heidelberg: Springer-Verlag.

Gerhards, Jürgen, and Rolf Hackenbroch. 2000. "Trends and causes of cultural modernization: an empirical study of first names." International Sociology 15/3, 501-531.

Hanks, Patrick, Kate Hardcastle, and Flavia Hodges. 2006. A Dictionary of First Names. $2^{\text {nd }}$ edt. Oxford: OUP.

Keber, Janez. 2008. Leksikon imen: onomastični kompendij. $4^{\text {th }}$ edt. Celje: Celjska Mohorjeva družba.

Lenarčič, Simon. 2012. Vse o imenih v Sloveniji. Ljubljana: Modrijan.

Onysko, Alexander. 2007. Anglicisms in German: Borrowing, Lexical Productivity and Written Codeswitching. Berlin: Walter de Gruyter.

Onysko, Alexander. 2009. "Exploring discourse on global English: a case study of discourse on anglicisms in German." English Today 25/1, 25-36.

Onysko, Alexander, and Esme Winter-Froemel. 2011. "Necessary loans - luxury loans? Exploring the pragmatic dimension of borrowing." Journal of Pragmatics 43, 1550-1567.

Prince, Ellen F. 1988. "On pragmatic change: the borrowing of discourse functions." Journal of Pragmatics 12/5-6, 505-518.

Sicherl, Eva. 2015. "The English-Slovene language contact: Borrowing of personal names." Linguistica 55/1, 273-289.

Sicherl, Eva. 2017. "Sposojanje angleških osebnih imen na Slovenskem: Socio-pragmatični vidik." Philological Studies 15/2, 64-79. 
Šabec, Nada. 2018. "The integration of English words in Slovene: Orthographic apects." In: E. Sicherl (ed), V družbi z jezikom in gorami: Zbornik ob jubileju Stanka Klinarja. Ljubljana: Znanstvena založba Filozofske fakultete.

Treffers-Daller, Jeanine. 2010. “Borrowing.” In: J. Verschueren, J.-O. Östman, J. Blommaert, and C. Bulcaen (eds), Handbook of Pragmatics Online. Amsterdam/ New York: John Benjamins.

Statistični urad Republike Slovenije (SURS) https://www.stat.si/ImenaRojstva/sl (accessed July and August 2017) and http://pxweb.stat.si/pxweb/Dialog/Saveshow.asp (accessed September 2017)

Corpus Nova beseda (accessed October 2017)

Eva Sicherl

University of Ljubljana, Slovenia Eva.Sicherl@ff.uni-lj.si

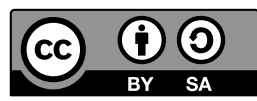

\section{Anglo-ameriški kulturni vpliv v Sloveniji: primer osebnih imen}

Prispevek se osredotoča na težnjo slovenskih staršev po poimenovanju svojih otrok z imeni, ki so sposojena iz angleščine. Statistični podatki potrjujejo, da se je v zadnjih desetletjih povečal vnos tujejezičnih in s tem tudi angleških osebnih imen, statistični seznami pa kažejo, kako pri osebnih imenih eksoticizmi (npr.Liam, Patrick, Nick, ki se uvrščajo med dvesto najbolj priljubljenih imen za zadnje statistično obdobje 2001-2015) tekmujejo z imeni, ki so bila prevzeta in podomačena pred mnogimi leti (npr. Patrik), ali pa jih tokrat prvič uvajamo v slovenščino. Vnos imenskih sposojenk iz angleščine obravnavamo z vidika pragmatičnega sposojanja, kot to opisuje Andersen (2014). Podan je zgodovinski pregled sposojanja angleških osebnih imen $\mathrm{v}$ slovenščino ter opisana vloga angleščine kot jezika dajalca. Takšne pragmatično sposojene prvine izkazujejo tudi sociolingvistične značilnosti sposojevalcev, ki jih analiziramo s pomočjo vprašalnika, ki so ga izpolnjevali starši vrtčevskih otrok v starosti 2-6 let. Ob tem skušamo ovrednotiti vpliv anglo-ameriške kulture na Slovenskem v tem segmentu.

Ključne besede: kulturni vpliv, angleščina, slovenščina, osebna imena

The author acknowledges the financial support from the Slovenian Research Agency (research core funding No. P6-0218). 